\title{
Latin American liberation theology: Does it fit in the schema of African theology of reconstruction?
}

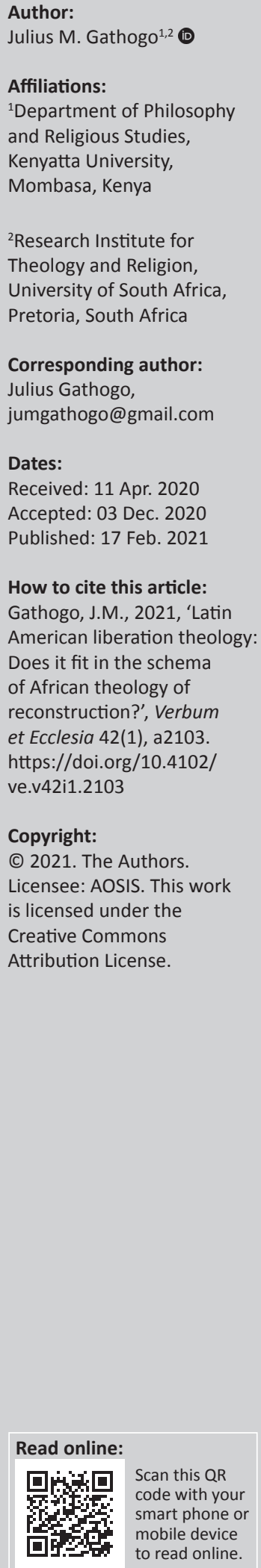

Three decades after the proposal for a shift of theological paradigm, from liberation to reconstruction in an African context (1990-2020), it is worthwhile to ask: Was this proposal timely? Did the proposal speak for other related theologies of liberation in the majority-world such as Black theology of North America and more specifically, Latin American liberation theology? In this proposal, African theologies of liberation were urged to embrace this shift as the new norm. Such African theologies includes: African theology (the mother), Black theology of South Africa, and African women's theology among others. Hence the proposal was contextual in that Africa was moving towards total independence from 'Pharaohs' who had colonised Africa since the Berlin conference of 1885/1886. With the African agenda appearing to have been taken care of, it is worthwhile to ask: Does this 'well-taken care of' African agenda mean anything to other liberationists theologians in the majority-world such as the Latin American liberation theology? This article sets on the premise that liberation theology can be done within reconstruction theology and vice versa, and as the situation and context demands. Hence, it is possible to cry for 'liberation' when in reality, it is liberation to reconstruct and/or liberation to consolidate the gains of previous liberation hence reconstruction. In its method and design, the article reviews the existing literature while making a critical analysis on matters under consideration.

Intradisciplinary and/or interdisciplinary implications: This article explores the notion of reconstruction in an African context and gives it a global dimension by drawing from other contemporary theologies of the Majority-World such as Latin American theology and Black theology of North America. It involves the disciplines of Systematic theology, Contemporary theology, Liberation and Reconstruction theologies, and Missiology.

Keywords: Latin American liberation theology; African theology of reconstruction; Liberation theology; Majority World theologies; Black theology.

\section{Introduction}

The General Committee of the All Africa Conference of Churches (AACC) oversaw the remaking of African theological discourses with Jesse Mugambi, the renowned Kenyan philosophertheologian and others. Presenters also included the Congolese theologian Kä Mana who read his paper on: Théologie Africaine pour temps de crise: Christianisme et reconctruction de l'Afrique, and was published in 1993, two years before Mugambi published his book, From liberation to Reconstruction in 1995. Generally, the papers that were presented sought to change the old patterns in African theology. The proceedings of 30 March 1990 were published in a book, The Church of Africa: Towards a Theology of Reconstruction in 1991, which Mugambi edited jointly with J.B. Chipenda, A. Karamaga and C.K. Omari. In this meeting of 30 March 1990, Mugambi perceptively proposed in his paper 'Future of the Church and the Church of the Future in Africa', ${ }^{1}$ that Africa must shift her theological gear from the paradigm of liberation to reconstruction. He noted that 'reconstruction is the new priority for African nations' (eds. Chipenda et al. 1991:36) and that reconstruction is a 'process will require considerable efforts of reconciliation and confidence-building. It will also require reorientation and retraining' (Mugambi 1991:36).

In a sense, Mugambi was speaking from an African ritualistic perspective where events shift from time to time, and as the need arises. Such needs include, the handover of leadership after 40 or so years when the older generations would hand-over the mantle to an incoming one (called Itwika, meaning 'break away' amongst the Kikuyu of Kenya). As a person from the Embu community of central Kenya, Mugambi was simply saying: 'Maguta makuru mati-inaga rwimbo',

1.This article appears in the book, The Church of Africa: Towards a Theology of Reconstruction, 1991:29-50, which Mugambi edited jointly with J.B. Chipenda, A. Karamaga and C.K. Omari. It also appears in his book, From liberation to reconstruction: African Christian theology after the Cold War, 1995:160-180 - in chapter 10. 
meaning, 'old oilskin does not enter into the dancing room'; hence, the need to 'break away' from the old pattern. In his understanding liberation, as a concept, became the old oil, whilst reconstruction, as a theological concept, became the new dancing oil for African discourses. This Kikuyu cultural Itwika, ${ }^{2}$ which is the same as the Ntuiko of the Meru, finds its parallelism with 'the eunoto ceremony'4 (Muriuki 1974:100) of the Maasai community.

Similarly, formal African Women's theology (informal African Women's theology must be much older than 1989), which emerged in the scholarly world in 1989 (Gathogo 2008:75), seeks to reconstruct the society by first working for the deconstruction of patriarchy. In seeking the liberation of women, it eventually seeks to reconstruct the entire society of men and women to awake to the fact that gender disparities are injustices to all (Gathogo 2008:75-92). In the same way, Black theology of South Africa and the African Christian theology (Gathogo 2007), ${ }^{5}$ use the concept of liberation as a major framework in their theological articulation. The concept of liberation remains, not just within the African theology of reconstruction, but also in other theologies of the Majority World. Other theologies of the Majority World include: Black theology of North America, Latin American theology and the Asian theologies, amongst others. As noted, all these Majority World theologies find their common denominator in the concept of liberation. A critical exploration on them, it is hoped, will drive us to draw some comparisons, with the former, in the light of the African theology of reconstruction.

With Gustavo Gutierrez, the Roman Catholic Peruvian Priest, guiding liberation theology innovatively, the movement has reinvigorated the marginalised people throughout Latin America. Despite utilising Marxism as an ideological tool of analysis, Latin American theology, as will be demonstrated in this article, also utilises a formal systematic theological approach. Owing to its radical leanings, it was ultimately opposed by the Vatican. By implicating both the church and society in the destiny of the oppressed, the Roman Catholic Church leadership felt uncomfortable with it since 1960s when it began. Latin American theology, however, seeks to fight poverty by addressing its alleged source, which is largely seen as emanating from the sin of greed. It explores the interface of Roman Catholic theology in particular and political activism.

\begin{abstract}
2.John Middleton, in his book, The Central tribes of the North-Eastern Bantu, (1953) writes that there is no evidence that the groupings that constitute the Kikuyu (as writes that there is no evidence that the groupings that constitute the Kikuyu (as
most publications describe the Kikuyu community) have ever united in war, even against neighbouring tribes (1953:30). He quotes C. Dundas who suggests that the Itwika ceremony probably provides an occasion for the most extensive regrouping known amongst the Kikuyu; in the district 'now known as Nyeri there seem to have been only three areas having separate Itwĩkas: these are the sections (now Government Divisions) of Tetu, Ndia and Mazera' (1953:30). However, 'these Divisions are clearly recognised by the Kikuyu as part of the Kikuyu proper, as opposed to Embu and Meru, the inhabitants of which cannot claim to be Kikuyu and cannot be admitted as tenants on Kikuyu land' (1953:30).
\end{abstract}

3.It means the shifting of existing patterns, especially with regard to authority in orde to create room for the incoming group (see, Fadiman 1982:127).

4.This eunoto ceremony by the Maasai, like the Kikuyu Itwika and the Meru ntuiko had 'the junior warriors taking over' from the previous ones (Muriuki 1974:100).

5.African Christian theology is also referred to as African theology in this article.
The key concern in this interface includes human rights, economic justice and poverty (Gutierrez 1973).

The article is thus, geared towards unveiling some of the concerns, which have appeared in the course of the research that culminated in this article. These concerns include: Can we, in sub-Saharan Africa, shift our theological gear, from liberation to reconstruction and ignore the other Africans in the Diaspora, ${ }^{6}$ or can we afford to ignore other people who have related or similar concerns in their theological articulations such as Latin American theologians? How do the theologies of the Majority World relate to one another? For us to seek a wider understanding, we shall attempt to revisit the theologies of liberation in the Majority World, but outside the sub-Saharan Africa. This will provide us with a rich dialogue considering that Mugambi (especially, 1989 and 1995) keeps on referring to them in his works, but does not go into the depth of these theologies. It will also be an important area of study considering that Mugambi has been involved in these theologies for the last four decades and, later called for a shift from liberation to a more inclusive paradigm.

The justification of this article is in the fact that no theology is done in isolation. Further, the Majority World theologies have commonalities which need in-depth analysis for better understanding of the same. In any case, Mugambi (1989, 1991 and 1995) in his works keeps on mentioning a variety of these theologies as his point of reference, and as a back-up to his two concepts of liberation and reconstruction. As reconstructive motif informs African Christianity, can the same be said of Latin American liberation theology? In other words, does it fit in the schema of African theology of reconstruction?

\section{Liberation Theology in the Americas}

'Liberation Theology in the Americas' refers to the theologies done in Latin American and North America by the so-called the marginalised groups. Certainly, it may appear difficult to differentiate them as they are all theologies from Americas - hence the description Liberation theologies in the Americas. The article, however, does not deal with the Black theology of North America, whose chief proponents such as James Cone are largely protestant theologians; as opposed to the Latin American liberation theology whose chief proponents such as Gutierrez, Bonino, Boff and others are largely Roman Catholic theologians.

In view of this, Wilmore and Cone (eds. 1979:450) have argued that the first encounter of Black theology of the United States of America (USA and Latin American theology) took place at a symposium in Geneva at the World Council of Churches (WCC) in May 1973. They go on to argue that this symposium was not for the purpose of discussions between

6.Africans in Diaspora refers to the black peoples around the world and in particular to the Americas and the Caribbean who found themselves in these places after slave trade was abolished in the 18 th century AD. 
these two theologies but rather, its goal was to introduce them both on the agenda of the WCC, 'whose theological focus was so decidedly European'. Thus, this contact was more of a dialogue between the traditional European theologians on the one hand and the Black and the Latin theologians on the other hand. It is the situation that dictated them to raise the question about their mutual relations as they jointly condemned the European theology. Interestingly, they began to concern themselves with matters to do with the differences and the similarities amongst Black theology and Latin American theology. By and by, they found themselves together addressing the issues of colour and class.

Curiously, whilst the first encounter between the Black theology and the Latin American theology took place in May 1973, the discourse between Black theology of USA and African theology took place much earlier. That is, it began in May 1969 when the Board of Directors of the National Conference of Black Churchmen (NCBC) strong-willed to take steps that would boost relations between the two theologies (see eds. Wilmore \& Cone 1979:447). Consequently, NCBC representatives attended the AACC in Abidjan, Ivory Coast, in September 1969. From there, numerous meetings followed which culminated in the creation of NCBC of a Pan-African Skills Project devoted to the recruitment of 'technically skilled Afro-Americans who have a sense of commitment toward the development of truly independent, progressive African nations ...' (ed. Massie 1973:134).

The effectiveness of the Pan-African Skills Project led to the first formal consultation between Black American theologians and African theologians in Dar es Salaam Tanzania, on 22-28 August 1971, under the joint sponsorship of the Tanzanian Council of Churches and the African Commission of NCBC. The papers and other documents prepared for this conference were published under the title Black Faith and Black Solidarity (eds. Wilmore \& Cone 1979:447).

On the other extreme, Black theology of the United States of America and Asian theology have not had a formal face-to-face dialogue. As Cone says,

'If Black Theology's dialogue with African Theology and Latin American Liberation Theology has been limited, the dialogue with Asian Theology has been almost non-existent ... In such ecumenical contexts as the World Council of Churches, especially in the Faith and Order Commission, we have met each other, but have seldom talked about our theologies'. (in eds. Wilmore \& Cone 1979:445-456)

One significant context for dialogue has been the Ecumenical Institute Bossey Colloquiums with African and Asian theologians, in which a number of black North American theologians have attended (eds. Wilmore \& Cone 1979:461). As seen in Mbiti's African and Asian contributions to Contemporary theology (ed. 1976) and Confessing Christ in Different Cultures (ed. 1977), there have been three colloquiums, two of which have been published as above books that are edited by Mbiti. The above analysis shows that
Black theology of the United States of America is closer to the African theology/Black theology of South Africa than with the Latin American Theology, or the Asian Theology. This is probably because of the historical factors that moved the black people to North America where they have now settled as African Americans. In their quest for identity, therefore the Afro-Americans have no choice but to trace their backgrounds and the common areas that need liberation. Consequently, it has immense influence on Black theology of South Africa and African theology in general - as the study will endeavour to show.

Going back to the relationship between Black theology of the United States of America and Latin American Liberation Theology, the Second dialogue (after that of May 1973) occurred at the Detroit Conference on Theology in 1975. The papers and the proceedings of the conference were published under the title Theology in the Americas, eds., Torres and Eagleson (1976). The 1975 conference began with presentations from Latin American theologians, José Míguez Bonino, Juan L. Segundo, Javier Iguiniz, Enrique Dussel, José P. Miranda, Leonardo Boff, Hugo Assmann and Beatriz M. Couch and Gustavo Gutiérrez (eds. Wilmore \& Cone 1979:451).

The 1975 Detroit Conference was held amidst tension between Black theology of the United States of America and Latin American Liberation theology. In fact, it began 9 months before its occurrence, that is - when black theologians were first invited to the conference. This tension was caused by the announced statement of invitation, which read:

'The intention of the planners of the "Theology in the Americas: 1975" Conference is to invite a group of Latin American theologians representing the theology of liberation, to dialogue with North American theologians concerning the context and methodology of this new theological current. It is hoped that such a dialogue would help both groups: the Latin Americans to understand the complex reality of the US; the North American theologians to initiate a process of evaluation of the American reality from the viewpoint of the poor and the oppressed'. (eds. Wilmore \& Cone 1979:451)

This statement caused more tensions between the two. In particular, the Black theologians of the United States of America protested the assumption that they (North American theologians) do not practise theology from the perspective of the poor. According to Wilmore and Cone (eds. 1979:451), this assumption could only be true if by 'North American theologians one means white theologians exclusively, which is apparently what some persons had in mind'. Thus, black theologians and other minorities felt that the invitation to them was more of an afterthought. ${ }^{7}$ Black theologians wondered why the Latin Americans were not talking with the victims of the oppression in other countries rather

7.It is no wonder that some black theologians and other minorities who felt that the invitation to them was a mockery went on and expressed their displeasure to Sergio invitation to them was a mockery went on and expressed their displeasure to Sergio
Torres, who was the chief organiser and Executive Secretary of the Theology in the Americas. 
than the oppressors. The black theologians therefore felt that the behaviour of the Latin American theologians was negatively affecting the global interest in the understanding of the theological enterprise as it relates to the liberation of the victims.

In this Detroit Conference of 1975, Black theologians of the United States of America had various complaints. Amongst them is the resentment that the Latin American theologians' dogmatic position on class made the Black theologians of the United States of America to appear as if they had no creative contribution to make in the liberation process (eds. Wilmore \& Cone 1979:451). Moreover, since the conference was held amidst an oppressed black community in Detroit - at the White Roman Catholic Sacred Heart Seminary, which had little relation to the blacks, this made the blacks to resent the Latin theologians on their class position. In other words, why couldn't the meeting be held in another environment which would give the situation of blacks in the United States of America a facelift of concern?

Another concern from the historic Detroit meeting of 1975 is that most of the black theologians felt that Latin American theologians were insensitive to racism. On the other hand, the Latin American theologians contended that the Black theologians of the United States of America needed to be awakened from international capitalism. Interestingly, these divergences did not break the spirit of future dialogues between the two. In fact, the Detroit meeting left them understanding each other better and 'with the resolution to continue' their dialogue (eds. Wilmore \& Cone 1979:452).

According to Cone, the most momentous and rewarding dialogue between Latin and black theologians took place in Matanzas, Cuba from 25 February to 2 March 1979. This conference focussed on the theme of 'Evangelisation and politics'. It was sponsored by the Evangelical Theological Seminary of Matanzas and the Christian Peace Conference for Latin America and the Caribbean. Here, 78 theologians from Christian Churches of Europe, Asia, Africa, the United States of America, the Caribbean and Latin America debated on the theme of 'Evangelisation and politics' (eds. Wilmore \& Cone 1979:452). Cone's paper on 'Evangelisation and politics: A Black Perspective', addressed the question on Black theology's interpretation of the Conference theme, as defined in the context of its dialogue with Latin American theologians; hence vitalising the conference in a big way, and for the betterment of the conference. As Cone says, 'For the first time, the question of racism was faced head-on by Latin American Liberation theologians' (eds. Wilmore \& Cone 1979:453). This shows that the two theologies moved in the direction of uniting on tackling oppressive issues, for the Latin Americans had appeared to have ignored the question of race in the infamous Detroit Conference of 1975 - something which almost caused irreconcilable division amongst the two.

Having looked at the two conferences, that are the 1975 Detroit Conference and the Matanzas Conference of 1979, we realise that these meetings began with a lot of misunderstandings but ended up with a clear move towards common grounds in theological articulation. This strengthens my argument in this article that theologians ought to listen to one another rather than condemn one another. It has also strengthened my argument that Black theology of the United States of America and Latin American theology are both theologies of Liberation and are in line with Mugambi's scheme of thought, as he too dealt on the theme of liberation in his book, African Christian theology: An Introduction (1989). It also shows that theologies in the Americas are not identical as there are various points of agreement and assorted points of departure. This therefore prepares us to look specifically at the Latin American theology of liberation.

\section{Latin American theology and other Majority World theologies}

In his book, African Christian Theology, Mugambi (1989:53) says that the Latin American theology of Liberation emerged in the 1970s. This is an important dimension considering that African theology emerged officially in the 1960s. This observation implies that the probabilities of Black theology of the United States of America and the Latin American theology having been inspired and informed by African theology, albeit silently, are somewhat high. Mugambi (1989:53) goes on to say that the Christian theology of liberation emerged first in Latin America and then amongst the people of the African diaspora in the United States. It then emerged in the continent of Africa, especially in the South. He then says that it has already emerged in Asia.

This chronology of how liberation theology flowed can be contested by basing our arguments on our previous studies. First, Mugambi $(1991,1995)$ appears to be suggesting that 'even though African theology had already started more than 10 years before the emergence of Latin American theology, it however did not emphasize on the concept of liberation'. Seen in this light, then this is misleading because African theology has always embraced both the inculturation and liberation currents, and has a history which can be traced from the birth of Pan-Africanism and beyond. It therefore, has never been anything short of this, as we have noted, right from its very outset. Alternatively, and most likely, it could have been that Mugambi's position is a mere oversight, which went unnoticed before his book was published, and the error was not discovered in good time for correction. In any case, his works in general, does not appear to build on that position. Second, James Cone contends that Latin American theology of Liberation is a recent theology as compared to Black theology of the United States of America (eds. Wilmore \& Cone 1979:455). He goes on to cite this evidence by saying that there was little involvement of the church in radical change, or of theologians interpreting the Gospel in the context of revolution before the 1960s in Latin America: yet the likes of Martin Luther King Junior with their Non-Violence Movement were already in place, in as early as 1955 . 
To Cone therefore, Black theology of the United States of America like African theology, and unlike the Latin American theology, was operational by the 1960s; for according to him (1985:6-7), one of the three contexts of the origin of Black theology is the Civil Rights Movement. The other two contexts of the origin of Black theology of the United States of America are the publication of Joseph Washington's book, Black Religion (1964) and the rise of the black power movement (Cone 1985). Washington's book was written in the context of the hegemony of integration in the black-white relationships in North America, and his writings were in contrast with the then dominant view. He contended that there was a unique black culture; a distinctive black religion that can be placed alongside Protestantism, Catholicism, Judaism and Secularism. He went on to argue that black religion is not identical with white Protestantism, or any other expression of Euro-American Christianity (Cone 1985:8). The second context of the origin of Black theology is the rise of the black power movement. This movement was strongly influenced by Malcolm X, who ironically was a Muslim leader of the 1960s and believed in the philosophy of Black Nationalism. After 1963 and many more riots in the ghettoes of American cities, it became clear that many blacks agreed with Malcolm X's contention that America was not a dream, as Martin Luther King was telling his audiences during his civil rights campaigns, but a nightmare. This therefore, clarifies that Black theology, like African theology, can be traced right from the 1960s.

Thus, as early as the late 1950s Martin Luther King and other black church authorities had already begun to relate the Christian Gospel to the struggle for racial justice in North American society, which was clearly done within the concept of liberation. Consequently, the great majority of white churches and their conservative theologians denied that there was such a relationship of the Gospel to the struggle for racial justice. For them, therefore, religion and politics did not mix (Cone 1985:7). With the rise of the moral majority and its endeavour to impact political decisions, scores of these conventional white Christians no longer pursued this school of thought. Interestingly, Jerry Falwell, who was one of them, later regretted when he said to a group of Chicago black ministers that, 'Dr. King [who advocated the idea of juxtaposition of Gospel and struggle for justice $]^{8}$ was a true Saint ... I confess I was wrong' (Tinney 1981:68-73).

Mugambi's analysis on how liberation theology spread from Latin America to the United States of America and then Africa can also be contested based on our previous discoveries that Black theology of South Africa is older than Black theology of the United States of America. As we noted earlier, it began as early as in the 19th and 20th centuries when the racist missionary prompted the blacks to form their own independent churches. For in these mission churches (Catholic, Anglican, etc.), blacks were regarded as 'no more like grown up children who needed to be guided in every way' (Nthamburi 1991:14-15). It is from that background that the South African Christians begin to develop their Black theology which was based on their own experiences of racism. From this historical survey from a church historian - Prof. Zablon Nthamburi - we realise that Black theology of South Africa is older than the Black theology of the United States of America. For unlike some other theologies, 'black theology, did not arise in the seminary or the University. In fact, most of its early interpreters did not even hold advanced academic degrees ${ }^{\prime 9}$ (Cone 1985:6).

Seen from this light, both the South African Black theology and the North American Black theology came into being in their respective contexts of struggle, which began from a time earlier than when Latin America's Gustavo Gutierrez published his famous book on liberation, A Theology of Liberation in 1973 (Cone 1985:6). However, the phrase 'Liberation Theology' could have been used in the published work in 1973 for the first time but the theology of liberation was there long before 1973. Thus, Mugambi's contentious chronology on the emergence of the Christian theology of liberation by first appearing in Latin America and then amongst the people of the African diaspora in the United States, followed by the African continent, especially in the South, and last of all emerging in Asia (1989:53), can be reassembled from that background.

\section{Hermeneutical preferences in Latin American theology}

Boff and Boff (1987:34ff) contend that even though theology must take all the books of the Bible into account, hermeneutical preferences are inevitable. They go on to analyse the Biblical books that are favoured by the Latin American theology of liberation as follows:

\section{Exodus}

They argue that the book of Exodus recounts the epic of the politico-religious liberation of a mass of slaves who, 'through the power of the covenant with God, became the people of God' (Boff \& Boff 1987:34).

\section{The prophets}

The books of the prophets are important in that the individual prophets portray an uncompromising defence of the liberator God. The prophets' vigorous denunciation of injustices and speaking for the rights of the poor are highly regarded as factors for inspiration.

\section{The Gospels}

The Gospels are favoured for their centrality of the divine person of Jesus, his liberating actions and his death and resurrection.

9.This observation that Black theology did not emerge from the academic institutions, rather it emerged from the masses of people, can also be used to refer to all theologies of the Majority World, as they are driven by the context. From a wider perspective, it can also mean that academic institutions need not limit any theological reflection as revelation is above theology. 


\section{The Acts of Apostles}

The book of the Acts of Apostles is favoured by Latin American theologians for its portrayal as the ideal of a free and liberating Christian community.

\section{Revelation}

The book of Revelation - the last book in the Bible - is given a hermeneutical preference by the Latin Americans because in 'collective and symbolic terms, it describes the immense struggles of the people of God against all the monsters of history' (Boff \& Boff 1987:34).

\section{Other books}

Other books that are given a hermeneutical preference by the Latin Americans include the books of wisdom. These books are seen to embody the value of divine revelation that is contained in popular wisdom. The wisdom books include the proverbs, legends etc.

\section{Ezra and Nehemiah}

In some parts of Central America, after the indigenous communities flirted with the books of the Maccabees to inspire their faith in the context of armed uprising, Christians turned to the books of Ezra and Nehemiah. The reason for turning to these books as Boff and Boff (1987:35) explains is because the two books 'portray the efforts at restoring the people of God after the critical period in Babylon captivity'.

\section{Reconstruction in Latin American theology}

It will suffice to concede that even the pastors in Central America had sanctioned the armed uprising on the basis of the book of Maccabees which, as noted above inspired them to consider armed uprising. Nevertheless, the end of the war affected their hermeneutical preference as they found themselves more at home with the books of Ezra and Nehemiah as opposed to the former: for without war, it was now a period of national reconstruction. There was now, every need for Christians to turn to a systematic theological reflection of the books of Ezra and Nehemiah with a reconstructive motif that Mugambi $(1991,1995)$ is advising the African theology of the 21st century to shift to. For in his view, there is no need for any further 'armed uprising' as 'war' is over, just as in the case of Central America. War in Mugambi's outlook would refer to the several oppressive situations that have affected the people of Africa for quite some time. They include slavery, official racism (read apartheid), colonialism, cold war, political dictatorships amongst the post independent Africa, as evidenced by the embracing of political pluralism amongst others. Boff and Boff's (1987) views on Central America provides us with rich food for thought as we attempt to draw some parallelisms with Mugambi's (1991, 1995) proposal for a shift to a hermeneutical reflection on Ezra-Nehemiah's post-exilic theology of reconstruction. For, is the 'war' over in Africa of the twenty-first century? Does the introduction of multiparty, in the 1990s, for example, in the political systems of sub-Saharan Africa provide a real, genuine 'end of the war', thereby providing a clear forum for reconstruction in theo-social realms? How true is it that Africa lacked such a forum before the 1990s?

For us to understand the real picture of the difference between the Central and the Latin Americans, whose hermeneutical preferences differed with time as seen above, we need to go back in history. As Nthamburi (1991:9f) notes, Christianity was propagated amongst the people of Central and Latin Americas by the Portuguese and Spanish colonisers in the 16th Century. During those days, church and state relation was very good and so the colonisation of the natives was done in collaboration with the church. As the new colonial settlers settled in this part of the world, priests were sent to care for them 'spiritually' and of course to 'Christianise the natives' (Nthamburi 1991:9f). It is from this background that the Catholic Church became associated with the state apparatus 'with all the privileges that went with such prestige' (1991:10). As Pablo Perez (in Segundo 1985) says, although there were some individuals in the official set-up who tirelessly tried to improve the condition of the indigenous people, officially the church as a whole did not seem to do much. This provides us with a clear picture of the missionary-coloniser factor as a background to the quests for liberation, as is the case with sub-Saharan Africa.

\section{Methodology in doing Latin American theology}

Concerning the methodology of doing Latin American theology, Gutiérrez refers to it as 'a new way to do theology' (McGovern 1989:30-32). That is, doing theology by turning to social sciences and abandoning the traditional reliance of theology on methods drawn from philosophy. Thus it uses the social analysis and the experiences, which are related to the praxis. ${ }^{10}$ This use of social sciences involves borrowing from Marxists, who stress on the social analysis that guides revolutionary activity (1989:30-32).

With regards to Christology, Latin American liberation theologians have produced various works on the subject but they are yet to work out a systematic Christology, except for Boff's (1978b) Jesus Christ Liberator: A critical Christology for our time. Although there are several other works following the Christological theme, they are in the main either the prolegomena or the beginnings of a systematic Christology (see Sobrino 1978:33). This, we may argue, is a common problem amongst most of the Majority World liberation

10.Praxis - is from the Greek word Prasso (meaning to work). It involves a revolutionary action on behalf of the poor and the oppressed, and out of this, theological perceptions will (liberationists believe) continully emerge. In other words, praxis perceptions will (liberationists believe) continually emerge. In other words, praxis refers to the discovery and formation of theological 'truth' out of a given historica situation through personal participation in the struggle for the liberation of the oppressed. Gutierrez defines praxis as a transforming activity marked and illuminated by Christian love' (McGovern 1989:32). Thus praxis does not simply mean activism; it connotes transforming activity guided by theory and goals. This motivating force according to Gutiérrez therefore, is Christian love. 
theologies other than the African theology. It also confirms Mugambi's emphasis that the Exodus metaphor has dominated the theologies of liberation, almost to the exclusion of other metaphors (Mugambi 1995:2, 24). Further it is difficult to speak of Latin American Liberation Christology as if there were a single uniform perspective. There are several differing perspectives within the broad framework of what might be called a Latin American Liberation Christology (see, e.g., ed. Bonino 1984). However, we can still glean from the work of these theologians some pointers towards a liberation Christology.

In seeking to understand their philosophical and theological presuppositions, it is important to appreciate that Latin American Liberation theology assumes an analysis which presents history and society as fundamentally conflictual in nature. The conflict, as we implied on methodology, is seen to be essentially one between the dominator and the dominated, between the oppressor and the oppressed. As Gutiérrez (1973) points out,

'[... L ] iberation expresses the aspirations of oppressed peoples and social classes, emphasizing the conflictual aspect of the economic, social, and political process which puts them at odds with wealthy nations and oppressive classes'. (p. 36)

Hence the apparent 'Marxism' in its sociological analysis. From the perspectives gained through the sociology of knowledge, Latin American theologians address the situation of oppression by turning to the theory of dependence. From the Marxist methodological background, they identify the problem in their situation as one of imbalance between the centre and the periphery.

\section{Gutiérrez (1973) sums up their insights thus:}

'The underdevelopment of poor countries, as an overall social fact, appears in its true light: as the historical by-product of the development of other countries. The dynamics of the capitalist economy lead to the establishment of a centre and a periphery, simultaneously generating progress and growing wealth for the few, and social imbalances, political tensions, and poverty for the many'. (p. 84)

Probably, it is because of the above reasoning that they prefer to use the notions of 'domination' and 'dependence' to interpret their own experience, and view development and underdevelopment as two mutually related processes.

Bonino (1975) explains that the 'basic categories for understanding our history are not development and underdevelopment, but domination and dependence. This is the crux of the matter' (p. 16). He goes on to explain that development and underdevelopment are not two successive stages in 'an abstract and mechanical process but two dimensions of one single historical movement' (1975:26-27). In this case, therefore, Latin America is the dependent part of this process.

Bonino hints that the contradictions that arise in this situation gives rise to the struggle for liberation from domination.
He says that the process that they have analysed, nonetheless 'develops at the same time its own internal contradictions, in and through which dependent men and society claim their humanity and begin a struggle for liberation' (1975:31). Thus the concept of 'liberation', to the Latin Americans, replaces 'development' because it better expresses the aspirations of the oppressed. ${ }^{11}$

In concluding this sub-section, it is important to accentuate the fact that even though African theology has never been directly influenced by the Latin American theology of liberation, they both have a common point of departure. That is, the historic and the socio-economic condition; for as Nthamburi (1991) says, African theology shares its concern of 'poverty and economic deprivation with its Latin American counter-part' (p. 10) as both are theologies of liberation.

The major difference between African theology and Latin American theology is seen in the fact that whilst African theology stresses on the importance of the situation in which theology is done, it does not however, share the Latin American emphasis on a Marxist analysis of society. In particular, African theologians do not appear to see any relationship between liberation and class struggle, nor do they entertain any ideological alliance with Marxism. For as Nthamburi (1991) appositely sums it up, African theology,

'... does not need Marx to tell them (that) they must be in solidarity with the oppressed. Africans can discern this from their traditional heritage and the Bible. What African theology needs to borrow from Latin American Liberation theology is the socio-economic motif ... Another aspect that we share with Latin American theologians is the exodus motif. The exodus becomes a model that any theology of liberation has to take. People need to identify with a spiritual and a political exodus. The exodus promises the oppressed and the poor that they will be delivered out of their situation of oppression in due course towards a situation of liberation'. (pp. 10-11)

\section{Conclusion and analysis}

The article set out to explore Latin American liberation theology and its potential to fit in the schema of African theology of reconstruction. Whilst geographical and demographic circumstances set them apart, the article has noted, as in the words of Gutierrez (1973:36) that the 'underdevelopment of poor countries, as an overall social fact, appears in its true light: the historical by-product of the development of other countries'. With the:

'[D]ynamics of the capitalist economy lead[ing] to the establishment of a centre and a periphery, simultaneously generating progress and growing wealth for the few, and social imbalances, political tensions, and poverty for the many'. (p. 36)

The situation shows that both the African and the context of Latino have a cut out duties, namely: to deconstruct neo-colonialism and eventually reconstruct their respective societies.

11.For details on the relationship between development and liberation in the Latin American situation, see Gutiérrez (1973). 
Second, the fact that there have been three colloquiums (as dialogue for Latin American theology and Black theology of North America), two of which have been published as books that are edited by John Mbiti before 1980, shows that dialogue will continue to yield dividends even for theology of reconstruction and Latin American theology and other third world theologies. Certainly, both Nthamburi (1991) and Gutierrez have correctly noted the common denominators amongst all theologies of the Majority World. There is therefore a sense in which liberation can be done within the reconstruction motif, particularly if liberation is done to consolidate the gains of 'freedom'. The fact that there has been tension between Black theology of North America and the Latin American liberation theology does not mean a common agenda cannot be arrived at.

Critically important is Boff and Boff's (1987:34ff, cf. Gathogo 2015) contention that hermeneutical preferences are inevitable in Christian theology, as another major point in understanding the dialogue between reconstruction theology and Latin American liberation theology. Some of the books that are favoured by Latin American theology of liberation include Acts of Apostles which is a historical narrative of the disciples turned Apostles, and the books of Ezra-Nehemiah. The latter are the key texts in building an African theology of reconstruction. Boff and Boff (1987:35) have explained that some parts of Central America once turned to Ezra-Nehemiah books after the indigenous communities flirted with the books of the Maccabees to inspire their faith in the context of armed uprising. They go on to say that Ezra-Nehemiah books "portray the efforts at restoring the people of God after the critical period in Babylon captivity' (1987:35).

Certainly, Latin American liberation theology fits well in the schema of African theology of reconstruction, as in the case of all Majority World theologies that are grappling with common concerns. This includes the deconstruction of patriarchy, liberation of women, environmental concern, economic justice for all, economic empowerment, quality education, human immunodeficiency virus (HIV) and acquired immune deficiency syndrome (AIDS), and the global pandemics such as coronavirus disease of 2019 (COVID-19). The common concerns in the Majority World context makes a clear case for liberation and reconstruction concepts as theological siblings for both Latin American and the African contexts. To an extent thus, global societies, African and Latinos inclusive, will always require an Itwika (a breakup from a past) and eventually reconstruct their societies in line with the emerging contexts. In the era of globalisation, common contexts suffice across the various regions of the world.

\section{Acknowledgements Competing interests}

The author has declared that no competing interests exist.

\section{Author's contributions}

I declare that I am the sole author of this research article.

\section{Ethical consideration}

This article followed all ethical standards for research without direct contact with human or animal subjects.

\section{Funding information}

I am grateful to Research Institute for Theology and Religion of the University of South Africa that gave me Research Output in 2019 thereby promoting further research.

\section{Data availability statement}

Data sharing is not applicable to this article as no new data were created or analysed in this study.

\section{Disclaimer}

The views and opinions expressed in this article are those of the authors and do not necessarily reflect the official policy or position of any affiliated agency of the authors.

\section{References}

Boff, L., 1978, Jesus Christ liberator: A critical Christological for our time, Orbis, Maryknoll, NY.

Boff, L. \& Boff, C., 1987, Introducing liberation theology, Burns and Oates, Kent.

Bonino, J.M., 1975, Revolutionary theology comes of age, Fortress Press, Philadelphia, PA.

Bonino, J.M., 1984, Faces of Jesus: Latin American Christologies, Orbis Books, Maryknoll, NK.

Chipenda, J.B., Karamaga, A., Mugambi, J.N.K. \& Omari, C.K. (eds.), 1991, The Church of Africa: Towards a theology of reconstruction, All Africa Conference of Churches, Nairobi.

Cone, J.H., 1985, 'A Black American perspective on the future of African theology', in K. Appiah-Kubi \& S. Torres (eds.), African Theology en Route, pp. 440-453. Orbis, Maryknoll, NY

Fadiman, L., 1982, An oral history of tribal warfare: The Meru of Mt. Kenya, Ohio University Press, Athens, $\mathrm{OH}$.

Gathogo, J., 2007, 'Black Theology of South Africa: Is this the hour of paradigm shift?', Black Theology: An International Journal 5(3), 327-354. https://doi.org/10.1558/ blth2007v5i3.327

Gathogo, J., 2008, 'Christology in African women's theology', African Theological Journal 31(2), 75-92.

Gathogo, J., 2015, 'Reconstructive hermeneutics in African Christology', HTS Teologiese Studies 71(3), 1-8. https://doi.org/10.4102/hts.v71i3.2660

Gutierrez, G., 1973, A theology of liberation: History, politics and salvation, Orbis Books, Maryknoll, NY.

Massie, P. (ed.), 1973, Black faith and black solidarity, Friendship Press, New York, NY.

Mbiti, J.S. (ed.), 1976, Africa and Asian contributions to contemporary theology, World Council of Churches, Geneva.

Mbiti, J.S. (ed.), 1977, Confessing Christ in different cultures, World Council of Churches, Geneva.

McGovern, A.F., 1989, Liberation theology and its critics: Toward an assessment, Orbis Books, Maryknoll, NY.

Middleton, J., 1953, The central tribes of the North-Eastern Bantu: The Kikuyu, including Embu, Meru, Mbere, Chuka, Mwimbi, Tharaka, and the Kamba of Kenya, International African Institute, London.

Mugambi, J.N.K., 1989, African Christian theology: An introduction, Heinemann, Nairobi.

Mugambi, J.N.K., 1991, 'The future of the church and the church of the future in Africa', in J.B. Chipenda, A. Karamaga, J.N.K. Mugambi \& C.K. Omari (eds.), The church of Africa: Towards a theology of reconstruction, pp. 29-50, All Africa Conference of Africa: Towards a
Churches, Nairobi.

Mugambi, J.N.K., 1995, From liberation to reconstruction: African Christian theology after the cold war, East African Educational Publishers Ltd, Nairobi.

Muriuki, G., 1974, A history of the Kikuyu: 1500-1900, Oxford University Press, Nairobi. Nthamburi, Z., 1991, 1995, The African Church at the crossroads, Uzima, Nairobi. 
Segundo, J.L., 1985, Theology and the church, Winston Press, Minneapolis, MN. Sobrino, J., 1978, Christology at the crossroads, Student Christian Movement, London.

Tinney, J.S., 1981, 'The moral majority: Operating under the hood of religious right', Dollars and Sense 7(2), pp. 68-73.
Torres, S. \& Eagleson, J. (eds.), 1976, Theology in the Americas, Orbis, Maryknoll, NY. Washington, J., 1964, black religion: The Negro and Christianity in the United States, University Press of America, Pennsylvania.

Wilmore, G.S. \& Cone, H.C. (eds.), 1979, Black theology: A documentary history, 1966-1979, Orbis, Maryknoll, NY. 